\title{
GOVERNANCE WITH COMPLEX STRUCTURES: EVIDENCE FROM WESTERN EUROPEAN COUNTRIES
}

\author{
Mário S. SANTOS ${ }^{1}$, António C. MOREIRA ${ }^{2}$, Elisabete S. VIEIRA ${ }^{3}$ \\ ${ }^{1} I P C$ - Instituto Politécnico de Coimbra, ISCAC, 3000-252 Coimbra, Portugal \\ ${ }^{2}$ GOVCOPP, DEGEI, University of Aveiro, Campus Universitário de Santiago, \\ 3810-193 Aveiro, Portugal \\ ${ }^{3}$ GOVCOPP, ISCA, University of Aveiro, Campus Universitário de Santiago, \\ 3810-193 Aveiro, Portugal \\ E-mails: ${ }^{1}$ msantos@iscac.pt; ${ }^{2}$ amoreira@ua.pt (corresponding author); \\ 3elisabete.vieira@ua.pt
}

Received 27 September 2012; accepted 31 January 2013

\begin{abstract}
This paper investigates if the existence of complex structures plays an important role in corporate governance. It uses GMM estimation on a panel of Western European firms. We find that the presence of a second and third large shareholder has a significant positive effect on firm value. This study underlines the importance of the number of blockholders as a determinant of firm value, when taken as a moderator of the contestability effect. It shows that the legal context and company-specific characteristics play a crucial moderating role for contestability. In contrast to previous research, we find that contestability plays a less relevant role in family firms. We also find that this last result does not vary significantly with the identity of the remaining elements of the coalition. Also, our study suggests that contestability is less important in companies led by majority shareholders.
\end{abstract}

Keywords: blockholders, contestability, firm value, family firms, investor protection, dynamic panel GMM.

JEL Classification: G3, G32.

\section{Introduction}

Why the sharing of company control is preferable to absolute control is still a key issue in corporate governance for firms with dominant shareholders. In fact, large companies have multiple small blockholders (Jara-Bertin et al. 2008; Laeven, Levine 2008; Attig et al. 2009; Konijn et al. 2011).

Four aspects drive this study. First, as there is no consensus on the virtues of blockholder dispersion, we aim to contribute to the debate on the existence of an optimal dispersion of ownership.

Second, we aim to test if the legal context moderates the contestability effect as suggested by Konijn et al. (2011). Third, conflicting results (Maury, Pajuste 2005; 
Jara-Bertin et al. 2008) when exploring non-family firms is an additional motivation of this paper. Finally, we aim to investigate if the identity of the second blockholder moderates the contestability effect.

We confirm that the existence of a second largest shareholder limits opportunistic behavior of the main blockholder. Moreover, for a given level of contestability, the effect on firms' value is dampened in coalitions of three blockholders vis-⿳亠丷⿵冂-vis coalitions with only two members. Altogether, the results suggest a complementarity between exit and voice governance mechanisms with the existence of an optimal number of blockholders.

This paper evidences the moderating role of ownership concentration contrasting with the results of Jara-Bertin et al. (2008) renewing the need for further research in this area. Moreover, the results suggest that excessive contestability reduces the effect on the value of firms. Also, our study suggests that contestability is significantly lower in family firms. Moreover, our result does not support Maury and Pajuste's (2005) or Jara-Bertin et al.'s (2008) work for family firms allowing only to conclude that the contestability effect when the two principal blockholder belong to the same groups of investors is small when compared with the contestability effect exerted by a blockholder that does not belong to the same group of investors as the main blockholder.

We confirm Bloch and Hege's thesis (2001) on the moderating role of the legal context. The paper is structured as follows. Section 1 describes the theoretical framework. We describe in Section 2 the sample selection and the research methodology. Section 3 presents the empirical results. Finally, we present the results and discuss our main findings.

\section{Theoretical background and hypothesis}

\subsection{Contestability and value}

In theory, there are two views regarding the role of the second largest owners. Winton (1993) argues that non-controlling shareholders with significant stakes have incentives to monitor controlling shareholders to avoid profit diversion. Also, decisions which may disadvantage small shareholders are prevented by bargaining problems among multiple controlling shareholders (Gomes, Novaes 2006). Also there is the possibility of collusion between the second and the largest shareholder to share private benefits. Whether the second controlling owner will monitor or collude with the first owner depends on the relative benefits of monitoring, which is proportional to the relative size of the ownership stake (Zweibel 1995).

Dhillon and Rossetto (2009) emphasize that the existence of many blockholders helps shift the voting outcome more towards the interests of minority shareholders. Edmans and Manso (2011) argue that the existence of a multiplicity of blockholders can form a forceful monitoring mechanism in disciplining the behavior of managers by aggressive trading of information.

Lehman and Weigand (2000) found evidence that the company's profitability increases with a second large shareholder. Volpin (2002) claimed that in Italy company market value is higher with blockholder syndicates than with a single blockholder. 
Maury and Pajuste (2005) studied the effect of multiple large shareholders on company valuation for a sample of Finnish listed companies. Their main result is that company value increases with control contestability.

Laeven and Levine (2008) find that higher valuations correlate with the voting rights of the second owner, confirming the research of Volpin (2002). Thus, we propose our first hypothesis:

H1: The value of companies increases as contestability of the main blockholder increases.

\subsection{The identity of the two largest shareholders and the effect of contestability on the value of companies}

The family firm has the advantage of joining control and management decisions, leading to reduced agency costs (Jensen 1986). Additionally, as families do care about their companies (they constitute most of their wealth, identity and patrimony), it is the family interest to avoid acting opportunistically with regard to the earnings obtained (Anderson, Reeb 2003) and to invest maximizing the value of the firm, thus benefiting the minority shareholders. As family control leads to higher firm valuation (Anderson et al. 2003; Barontini, Caprio 2006; Villalonga, Amit 2006), it would be expected that the contestability effect of the main blockholders would be lower in family firms.

On the other hand, the lack of alignment between family interests and those of other shareholders, involving management and control, may lead to investment decisions that do not necessarily maximize value and the interests of other shareholders (Fama, Jensen 1983; Barontini, Caprio 2006).

Consistent with the greater potential for expropriation in family-controlled firms, there is a broad consensus that contestability is more relevant in family companies (Maury, Pajuste 2005; Jara-Bertin et al. 2008; Attig et al. 2011). We thus formulate the following hypothesis:

H2: When the dominant blockholder is a family, the level of control rights in the hands of the second and third most significant shareholders will be more relevant for firm value than in non-family firms.

Now we examine whether the identity of the second owner vis-à-vis the identity of the largest owner matters for corporate valuation.

Maury and Pajuste (2005) suggest that two families can make profit diversion easier due to increased cohesion and cooperation in the controlling group when compared to a coalition formed by family and non-family shareholders. Jara-Bertin et al. (2008) confirm that family firms with a second largest reference shareholder have a negative effect on the value of firms. Hence, we formulate the following hypothesis:

H3: The contestability of the principal blockholder in family firms is less relevant when the two main shareholders belong to the same family.

\subsection{Legal system}

We aim to test Shleifer and Vishny's (1997) thesis who posit that monitoring by large minority shareholders is effective only in countries with good investor protection. When 
legal investor protection is high, collusion is more difficult between the investor and potential monitoring shareholders (Pagano, Roell 1998).

Diferently, Bennedsen and Wolfenzon (2000) maintain that in environments with poor shareholder protection, the most efficient ownership structure emerges in a control structure with multiple shareholders. Moreover, Bloch and Hege (2001) claim that when legal protection for minorities is weak, multiple blockholders provide some compensation.

We expect to confirm that the existence of complex structures plays an economically more relevant role, specifically in contexts where only voting rights provide a real chance to condition the behavior of the main shareholder, which is an empirical question not yet explored in Western Europe.

H4: The contestability of the principal blockholder is more relevant when the protection of shareholder rights is more fragile, according to a substitution effect between internal and external governance mechanisms.

\section{Data, variables and methodology}

\subsection{Data}

We use data on 938 non-financial listed firms across Belgium, Denmark, Finland, France, Germany, Greece, Italy, Netherlands, Portugal, Spain, Sweden, Switzerland, and the UK, from the AMADEUS database. We exclude financial firms and utilities. For each country we prepared a panel of non-financial companies with financial and ownership information available between 2002 and 2006.

We use total shareholding (percentage of total voting rights held by the shareholder where the path through which ownership is held may be direct or indirect) and excluded firms that have missing data for all control variables used. Since the focus is on the role of contestability, we also exclude firm-years that do not have any blockholder with at least $10 \%$ of the votes.

\subsection{Methodology}

In order to test the relationship between the contestability of the first largest blockholder by the second and the third largest blockholders and the market value of the firms, we consider the following model:

Tobin's $Q_{i t}=\alpha_{0}+\beta_{1}$ Tobin's $Q_{i, t-1}+\beta_{2}$ BLOCK1 $_{\text {it }}+\beta_{3}$ COALITION $_{i t}+\beta_{4}$ DEBT $_{i t}+$ $\beta_{5} \mathrm{ROA}_{\text {it }}+\beta_{6} \mathrm{SIZE}_{\mathrm{it}}+\beta_{7} \mathrm{INTANG}_{\mathrm{it}}+\beta_{8} \mathrm{GROWTH}_{\mathrm{it}}+\beta_{9} \mathrm{AGE}_{\mathrm{it}}+\zeta_{\mathrm{t}}+\lambda_{\mathrm{i}}+\delta_{\mathrm{s}}+\theta_{\mathrm{p}}+\varepsilon_{\mathrm{it}}$.

The dependent variable reflects the current value of expected future performance. The natural log transformation was performed in order to reduce problems of heteroscedasticity. To reduce the impact of extreme values, we impose a cut-off at the 5 th and 95 th percentiles (Barontini, Caprio 2006). 
For robustness purposes, we include additional control variables (Table 1) as adopted on previously (Aggarwal et al. 2011; Laeven, Levine 2008; Jara-Bertin et al. 2008; Maury, Pajuste 2005).

Table 1. Detailed definitions of the variables

\begin{tabular}{|c|c|}
\hline Variable & Description \\
\hline \multicolumn{2}{|c|}{ Dependent variable } \\
\hline Tobin's Q & $\begin{array}{l}\text { (TA-BVE+MVE)/TA, where TA is Total Assets; BVE is the book value of } \\
\text { equity and MVE is the market value of equity }\end{array}$ \\
\hline \multicolumn{2}{|c|}{ Independent and dummy variables } \\
\hline COALITION & $\begin{array}{l}\text { (BLOCK2+BLOCK3)/(BLOCK1+BLOCK2+BLOCK3), where BLOCK1, } \\
\text { BLOCK2 and BLOCK } 3 \text { are the control rights shares held respectively } \\
\text { by the largest, second largest and third largest shareholders of the } \\
\text { company }\end{array}$ \\
\hline BLOCK123 & $\begin{array}{l}\text { The percentage of control rights held jointly by the three major shareholders } \\
\text { of the company }\end{array}$ \\
\hline DTWO & Dummy that equals one when the coalition includes only two shareholders \\
\hline DTHREE & Dummy that equals one when the coalition includes three shareholders \\
\hline MJ & $\begin{array}{l}\text { Dummy that equals one if the largest shareholder has at least } 50 \% \text { of the } \\
\text { control rights. NMJ is a complementary dummy }\end{array}$ \\
\hline DMORE & $\begin{array}{l}\text { Dummy that equals one if the two largest shareholders have at least } 50 \% \text { of } \\
\text { control rights; DLESS is a complementary dummy }\end{array}$ \\
\hline DHIGH & $\begin{array}{l}\text { Dummy that equals one if the second and the third large shareholders } \\
\text { have joint control rights above those of the main blockholder; DLOW is a } \\
\text { complementary dummy }\end{array}$ \\
\hline FD & $\begin{array}{l}\text { Dummy that equals one if the largest shareholder is an individual or a family } \\
\text { with at least } 10 \% \text { of the control rights; NFD is a complementary dummy }\end{array}$ \\
\hline FFD & $\begin{array}{l}\text { Dummy that equals one if the two main blockholders belong to the same } \\
\text { family }\end{array}$ \\
\hline FNFD & $\begin{array}{l}\text { Dummy that equals one if in family firms the second blockholder does not } \\
\text { belong to the family }\end{array}$ \\
\hline SGD & $\begin{array}{l}\text { Dummy that equals one if the two main shareholders are the same group of } \\
\text { investors; NSGD is a complementary dummy }\end{array}$ \\
\hline ANGLO & $\begin{array}{l}\text { Dummy where a value of } 1 \text { is assigned for companies from the UK (Common } \\
\text { Law countries); NANGLO is a complementary dummy }\end{array}$ \\
\hline ASD1 & $\begin{array}{l}\text { Dummy where a value of } 1 \text { is assigned for companies from the countries with } \\
\text { an Anti-self-dealing index }>0.38 \text { (Belgium, Denmark, Finland, Italy, Portugal, } \\
\text { and the UK); ASD2 is a complementary dummy }\end{array}$ \\
\hline
\end{tabular}

Control variables

DEBT

$\mathrm{NCL} /(\mathrm{NCL}+\mathrm{MVE})$ where $\mathrm{NCL}$ is the book value of the long term debt and MVE is the market value of equity 
(End of Table 1)

\begin{tabular}{|c|c|}
\hline SIZE & Ln (Fixed Assets) \\
\hline INTANG & $\begin{array}{l}\text { INTANG }=\text { IFA/TA where IFA is the book value of the intangible fixed assets } \\
\text { and TA is total assets }\end{array}$ \\
\hline ROA & $\begin{array}{l}\text { EBITDA/TA where EBITDA denotes earnings before interest, taxes, } \\
\text { depreciation and amortization and TA is the book value of total assets }\end{array}$ \\
\hline GROWTH & $\left(R E V_{t}-R E V_{t-1}\right) / R E V_{t-1}$ where $R E V$ is the revenue \\
\hline LNAGE & $\begin{array}{l}\text { Ln (YEARS) where YEARS is the number of years since the firm began its } \\
\text { activity }\end{array}$ \\
\hline
\end{tabular}

When we explore the impact of the identity of the two largest owners, we categorize them into several investor groups: (i) family, when the principal blockholder is either a family or an individual; (ii) institutional investors, when the principal blockholder is either a financial company, an insurance company, a mutual pension fund/trust, a private equity company or a bank; (iii) corporate investors, when the principal blockholder is a non-financial company and (iv) other.

We included the following dummies: industry $\left(\delta_{\mathrm{s}}\right)$; time effects, $\left(\zeta_{\mathrm{t}}\right)$; a control for unobserved time-constant individual heterogeneity of firms $\left(\lambda_{\mathrm{i}}\right)$; country $\left(\theta_{\mathrm{p}}\right) \cdot \varepsilon_{\mathrm{it}}$ is a whitenoise error.

Table 1 provides information and definitions of all variables used.

To control dynamic endogeneity, unobservable heterogeneity, and simultaneity, and following Wintoki et al. (2012), we use the dynamic panel GMM estimator as proposed by Arellano and Bover (1995), Blundell and Bond (1998). However, as it has its limitations, we present two-step estimates, which in theory provide robust results.

As small panel samples may produce downward bias in estimated asymptotic standard errors in the two-step procedure we implemented the Windmeijer (2005) correction.

An optimal choice of instruments is a clear influence on the consistency of estimates. Therefore, we report a test for the second-order serial correlation, $m_{2}$ statistic (Arellano, Bond 1991). We use the Hansen J-statistic of over-identifying restrictions to test for the absence of correlation between the instruments and the error term. We also report a difference-in-Hansen test (Roodman 2009) that evaluates if supplementary instruments required for systems estimation and used in the levels equation are valid.

\section{Results}

\subsection{Descriptive results}

Consistent with prior studies, Table 2 shows that the principal owner holds, on average, $38.90 \%$ of voting rights, suggesting that the main agency problem in these firms stems from conflicts of interest between controlling and minority shareholders. Table 2 shows the relevance of focusing on the three main shareholders; on average they account for $63.90 \%$ of voting rights. 
Table 2. Descriptive statistics for the main variables

\begin{tabular}{|c|c|c|c|c|c|c|c|}
\hline Variable & Obs. & Obs. & Mean & Median & $\begin{array}{l}\text { Std. } \\
\text { dev. }\end{array}$ & Min. & Max. \\
\hline TOBIN's Q & 4,690 & 100.0 & 1.369 & 1.203 & 0.617 & 0.203 & 5.917 \\
\hline BLOCK1 & 4,690 & 100.0 & 38.9 & 36.1 & 20.1 & 10.0 & 95.0 \\
\hline BLOCK123 & 4,690 & 100.0 & 63.9 & 61.3 & 26.7 & 10.0 & 99.3 \\
\hline $\begin{array}{l}\text { FAMILY N } \\
\text { SHAREHOLDERS }\end{array}$ & 1,165 & 24.8 & 2.190 & 2 & 0.766 & 1 & 3 \\
\hline $\begin{array}{l}\text { NON-FAMILY N } \\
\text { SHAREHOLDERS }\end{array}$ & 3,525 & 75.2 & 1.985 & 2 & 0.776 & 1 & 3 \\
\hline COALITION & 3,350 & 71.4 & 0.428 & 0.358 & 0.226 & 0.101 & 0.667 \\
\hline FAMILY - COALITION & 913 & 27.3 & 0.445 & 0.464 & 0.134 & 0.111 & 0.667 \\
\hline $\begin{array}{l}\text { NON-FAMILY - } \\
\text { COALITION }\end{array}$ & 2,437 & 72.7 & 0.421 & 0.437 & 0.139 & 0.101 & 0.667 \\
\hline COALITION20 & 1,576 & 33.6 & 0.426 & 0.443 & 0.210 & 0.250 & 0.667 \\
\hline FD & 1,165 & 24.8 & 0.248 & 0.000 & 0.432 & 0.000 & 1.000 \\
\hline DEBT & 4,690 & 100.0 & 0.275 & 0.241 & 0.207 & 0.000 & 0.989 \\
\hline SIZE & 4,690 & 100.0 & 12.253 & 11.745 & 2.825 & 5.858 & 20.433 \\
\hline INTANG & 4,690 & 100.0 & 0.204 & 0.153 & 0.181 & 0.000 & 0.969 \\
\hline ROA & 4,690 & 100.0 & 0.106 & 0.104 & 0.088 & -0.403 & 0.643 \\
\hline GROWTH & 4,690 & 100.0 & 0.069 & 0.027 & 0.480 & -0.979 & 16.717 \\
\hline AGE & 4,690 & 100.0 & 44.91 & 30.00 & 44.28 & 1 & 628 \\
\hline
\end{tabular}

Note: This table reports summary statistics for a sample of 938 firms $(4,690$ observations $)$ between 2002 and 2006.

Table 3 provides insights into the distribution of shares among large shareholders. Consistent with previous studies (Jara-Bertin et al. 2008; Laeven, Levine 2008), we notice a complex ownership structure (with at least two large blockholders) in $71.43 \%$ of the sample.

\subsection{Regression results}

\subsubsection{Contestability and company value}

The results in Table 4 for COALITION, confirm the positive effect of contestability of the first shareholder on the value of firms. The coefficient estimate in column 1 of Table 4 is positive (0.222), which supports H1 and is consistent with Bloch and Hege's (2001) model.

Furthermore, control variables included in the analysis strongly influence the regression results and have the expected coefficients according to previous research (Maury, Pajuste 2005; Laeven, Levine 2008; Aggarwal et al. 2011). 
Table 3. Ownership concentration and the importance of complex structures

\begin{tabular}{lccccc}
\hline $\begin{array}{l}\text { OWNERSHIP } \\
\text { STRUCTURE }\end{array}$ & $\begin{array}{c}\text { PREVALENCE } \\
\text { number } \%\end{array}$ & BLOCK1 & BLOCK2 & BLOCK3 \\
\hline $\begin{array}{l}\text { ONE CONTROLLING } \\
\text { SHAREHOLDER }\end{array}$ & 1,340 & 28.57 & $36.26 \%$ & - & - \\
\hline $\begin{array}{l}\text { MULTIPLE LARGE } \\
\text { SHAREHOLDERS }\end{array}$ & 3,350 & 71.43 & - & - & - \\
\hline of which 2 large & 1,842 & 54.99 & $43.80 \%$ & $20.93 \%$ & \\
\hline of which 3 large & 1,508 & 45.01 & $35.31 \%$ & $20.83 \%$ & $14.89 \%$ \\
\hline TOTAL & 4,690 & 100.00 & $38.83 \%$ & $20.88 \%$ & $14.89 \%$ \\
\hline
\end{tabular}

Notes: This table reports the total number and the percentage of firms in the sample with (i) one controlling owner, and (ii) multiple large shareholders.

Table 4. Relation between firm value and the contestability effect. Moderating role of ownership concentration and the number of blockholders

\begin{tabular}{|c|c|c|c|c|c|}
\hline & (1) & (2) & (3) & (4) & $(5)$ \\
\hline Ln (TOBIN's $\left.Q_{\text {i.t-1 }}\right)$ & $\begin{array}{c}0.377 * * * \\
(6.26)\end{array}$ & $\begin{array}{c}0.379 * * * \\
(6.09)\end{array}$ & $\begin{array}{c}0.348 * * * \\
(5.78)\end{array}$ & $\begin{array}{c}0.371 * * * \\
(5.85)\end{array}$ & $\begin{array}{c}0.398 * * * \\
(6.68)\end{array}$ \\
\hline$B L O C K 1$ & $\begin{array}{c}0.002 * * * \\
(2.68)\end{array}$ & $\begin{array}{c}0.002 * * * \\
(2.97)\end{array}$ & $\begin{array}{c}0.002 * * * \\
(2.96)\end{array}$ & $\begin{array}{c}0.002^{* * *} \\
(2.69)\end{array}$ & $\begin{array}{c}0.002 * * * \\
(2.67)\end{array}$ \\
\hline COALITION & $\begin{array}{c}0.222 * * * \\
(3.07)\end{array}$ & & & & \\
\hline COALITION* ${ }^{*} \mathrm{MJ}$ & & $\begin{array}{c}0.216^{* * * *} \\
(2.78)\end{array}$ & & & \\
\hline COALITION* NMJ & & $\begin{array}{c}0.383 * * * \\
(3.88)\end{array}$ & & & \\
\hline COALITION*DMORE & & & $\begin{array}{c}0.143 * * * \\
(2.79)\end{array}$ & & \\
\hline COALITION*DLESS & & & $\begin{array}{c}0.403 * * * \\
(3.42)\end{array}$ & & \\
\hline COALITION*DHIGH & & & & $\begin{array}{c}0.175 * * * \\
(3.55)\end{array}$ & \\
\hline$C O A L I T I O N^{*} D L O W$ & & & & $\begin{array}{c}0.277 * * * \\
(3.28)\end{array}$ & \\
\hline COALITION*DTWO & & & & & $\begin{array}{c}0.328 * * * \\
(3.64)\end{array}$ \\
\hline COALITION* DTHREE & & & & & $\begin{array}{c}0.191 * * * \\
(4.08)\end{array}$ \\
\hline$D E B T$ & $\begin{array}{c}-0.350 * * * \\
(-3.54)\end{array}$ & $\begin{array}{c}-0.320 * * * \\
(-3.34)\end{array}$ & $\begin{array}{c}-0.297 * * * \\
(-2.98)\end{array}$ & $\begin{array}{c}-0.395 * * * \\
(-3.89)\end{array}$ & $\begin{array}{c}-0.318 * * * \\
(-3.52)\end{array}$ \\
\hline
\end{tabular}


(End of Table 4)

\begin{tabular}{|c|c|c|c|c|c|}
\hline & (1) & (2) & (3) & (4) & (5) \\
\hline SIZE & $\begin{array}{c}-0.061 * * * \\
(-3.56)\end{array}$ & $\begin{array}{c}-0.062 * * * \\
(-3.41)\end{array}$ & $\begin{array}{c}-0.077 * * * \\
(-4.22)\end{array}$ & $\begin{array}{c}-0.071 * * * \\
(-3.83)\end{array}$ & $\begin{array}{c}-0.073 * * * \\
(-3.98)\end{array}$ \\
\hline$I N T A N G$ & $\begin{array}{l}0.302 * * * \\
(2.64)\end{array}$ & $\begin{array}{c}0.349 * * * \\
(3.04)\end{array}$ & $\begin{array}{c}0.258^{* *} \\
(2.18)\end{array}$ & $\begin{array}{c}0.262 * * \\
(2.22)\end{array}$ & $\begin{array}{c}0.294 * * \\
(2.43)\end{array}$ \\
\hline$R O A$ & $\begin{array}{c}0.460 * * * \\
(3.36)\end{array}$ & $\begin{array}{c}0.418^{* * * *} \\
(3.23)\end{array}$ & $\begin{array}{c}0.443 * * * \\
(3.20)\end{array}$ & $\begin{array}{l}0.257^{*} \\
(1.79)\end{array}$ & $\begin{array}{c}0.352 * * * \\
(3.21)\end{array}$ \\
\hline GROWTH & $\begin{array}{c}0.033 * * * \\
(2.62)\end{array}$ & $\begin{array}{l}0.028^{* *} \\
(2.45)\end{array}$ & $\begin{array}{c}0.014 * * \\
(2.23)\end{array}$ & $\begin{array}{c}0.026^{* * *} \\
(2.23)\end{array}$ & $\begin{array}{c}0.033 * * * \\
(2.69)\end{array}$ \\
\hline$L N A G E$ & $\begin{array}{c}-0.111 * * * \\
(-3.16)\end{array}$ & $\begin{array}{c}-0.098 * * * \\
(-2.66)\end{array}$ & $\begin{array}{c}-0.118 * * * \\
(-2.87)\end{array}$ & $\begin{array}{c}-0.076^{*} \\
(-1.83)\end{array}$ & $\begin{array}{c}-0.099 * * * \\
(-2.61)\end{array}$ \\
\hline Constant & $\begin{array}{c}1.331 * * * \\
(4.89)\end{array}$ & $\begin{array}{c}1.222 * * * \\
(4.11)\end{array}$ & $\begin{array}{c}1.534 * * * \\
(4.95)\end{array}$ & $\begin{array}{c}1.369 * * * \\
(4.38)\end{array}$ & $\begin{array}{l}1.434 * * * \\
(5.05)\end{array}$ \\
\hline Number of instruments & 54 & 61 & 58 & 55 & 63 \\
\hline $\begin{array}{l}\text { Wald }\left(\mathrm{H}_{0}-\text { test of }\right. \\
\text { equality of interaction } \\
\text { variables })\end{array}$ & - & 0.006 & 0.003 & 0.048 & 0.005 \\
\hline $\mathrm{m}_{2}$ (p-value $)$ & 0.674 & 0.388 & 0.997 & 0.772 & 0.763 \\
\hline $\begin{array}{l}\text { Hansen J-statistics } \\
\text { ( } p \text {-value) }\end{array}$ & 0.506 & 0.602 & 0.697 & 0.554 & 0.767 \\
\hline $\begin{array}{l}\text { Diff-in-Hansen test } \\
\text { ( } p \text {-value) }\end{array}$ & 0.567 & 0.645 & 0.356 & 0.927 & 0.969 \\
\hline
\end{tabular}

Notes: Figures in parentheses are t-statistics (t-statistics are based on robust, firm-clustered standard errors) while p-values are in brackets. ${ }^{*}, * *$ and $* * *$ indicate statistical significance at 10,5 , and $1 \%$ levels.

We decided to test if the contestability effect is moderated by the concentration of ownership. First, we test a restriction on the first largest shareholder having control rights above or below $50 \%$, the majority control threshold. We find that the COALITION coefficient (Table 4 column 2 ) for firms with no majority blockholders $(0.383)$ is larger than the coefficient for other firms (0.216). The results suggest, unlike those evinced by Jara-Bertin et al. (2008), that the effect of contestability is higher among firms that do not have a majority shareholder. In our view, our results are more in line with basic economic rationale that supports that the majority shareholders would be more independent in their decisions and thus the contestability effect would be expected to be less intense.

The interaction of contestability and ownership concentration in the hands of the two largest shareholders is tested in the model presented in column 3 of Table 4 . The results show that this relationship is stronger when the two largest shareholders together have voting rights below $50 \%(0.403)$ than in other cases $(0.143)$. The hypothesis that both coefficients are statistically equal is rejected by the Wald test at $1 \%$ level. We conclude that when the coalition has majority stakes the likelihood of collusion behaviors increases and the contestability effect decreases. In any case, the contestability effect remains positive. 
In model 4 of Table 4 we test another cut-off point that seems particularly relevant, determined by the sum of voting rights of the second and third shareholder being greater than the voting rights of the main blockholder, which happens in our sample in $21.51 \%$ of the observations. Our results suggests that minority shareholders anticipate one of two possible negative outcomes: (i) excessive conflict among the three major shareholders that may impede the implementation of interesting projects for the company as a result of different sensitivities to risk, and difficulties in agreeing on how best to finance these investments; (ii) largely equal control rights between the three principal shareholders may, on the contrary, determine a shared set of objectives between these behaviors and result in collusion to the detriment of other shareholders.

As a complement, we explore if the existence of complex structures with three blockholders is more interesting than with only two. Column 5 of Table 4 shows the coefficients of two interaction variables that for the same level of contestability, where the effect on the value of companies is seen to be substantially higher if performed by a single contestant (0.328) than by structures with three blockholders (0.191). The hypothesis that both coefficients are statistically equal is rejected at $1 \%$ level.

These results suggest that: (i) the circumstances of a coalition including three shareholders make the negotiation process particularly difficult when compared to a situation of having only to reconcile the interests of the two major shareholders; (ii) an alternative explanation can also found in the circumstance that the interests of the second and third are not necessarily aligned and therefore did not have a monolithic behavior with the principal shareholder; (iii) a third and final possibility is that the second or third blockholder is aligned with the interests of the main shareholder, which results in a dramatic reduction in contestability.

\subsubsection{Is the effect of contestability on the company value moderated by the identity of the two largest shareholders?}

We explored the interaction between the variable COALITION and the identity of the first large shareholder by estimating the models presented in column 1 of Table 5 . We found that the COALITION coefficient for family firms $(0.161)$ is smaller than the coefficient for non-family firms (0.341). Equality of the coefficients is rejected at the $5 \%$ level. This is an unexpected result, which does not support H2, and contradicts previous empirical evidence as reported by Maury and Pajuste (2005) and Jara-Bertin et al. (2008).

Our evidence means that the minority shareholders in family firms anticipate that the remaining blockholders have a lower propensity to challenge the main blockholder than in other companies. The following factors help in the explanation of our results: (i) research is almost unanimous regarding the positive effect family firm leadership has on firm value (Anderson et al. 2003; Villalonga, Amit 2006). This may mean a greater coincidence of interests between major family blockholders and other minority shareholders. Moreover, family firm shareholders concentrate much of their wealth and have on average higher equity capital than other groups of shareholders. These two 
Table 5. Relation between firm value and the contestability effect. The moderating role of identity and the institutional context

\begin{tabular}{|c|c|c|c|c|c|}
\hline & (1) & (2) & (3) & (4) & (5) \\
\hline Ln (TOBIN's $\left.Q_{i . t-1}\right)$ & $\begin{array}{c}0.384^{* * * *} \\
(6.81)\end{array}$ & $\begin{array}{c}0.356^{* * *} \\
(6.29)\end{array}$ & $\begin{array}{c}0.365^{* * * *} \\
(5.91)\end{array}$ & $\begin{array}{c}0.506^{* * *} \\
(11.87)\end{array}$ & $\begin{array}{c}0.404 * * * \\
(6.78)\end{array}$ \\
\hline$B L O C K 1$ & $\begin{array}{c}0.001 * * * \\
(2.87)\end{array}$ & $\begin{array}{c}0.001 * * * \\
(2.21)\end{array}$ & $\begin{array}{c}0.002 * * * \\
(2.60)\end{array}$ & $\begin{array}{c}0.002 * * * \\
(3.54)\end{array}$ & $\begin{array}{c}0.001 * * * \\
(2.61)\end{array}$ \\
\hline COALITION* FD & $\begin{array}{c}0.161 * * * \\
(2.61)\end{array}$ & & & & \\
\hline COALITION* NFD & $\begin{array}{c}0.341 * * * \\
(3.37)\end{array}$ & & & & \\
\hline COALITION* FFD & & $\begin{array}{c}0.143 * * \\
(2.03)\end{array}$ & & & \\
\hline COALITION* FNFD & & $\begin{array}{c}0.188 * * * \\
(2.76)\end{array}$ & & & \\
\hline COALITION* NFD & & $\begin{array}{c}0.356^{* * * *} \\
(3.54)\end{array}$ & & & \\
\hline$C O A L I T I O N * S G D$ & & & $\begin{array}{c}0.154 * * * \\
(2.63)\end{array}$ & & \\
\hline COALITION*NSGD & & & $\begin{array}{c}0.309 * * * \\
(3.36)\end{array}$ & & \\
\hline COALITION*ANGLO & & & & $\begin{array}{c}0.145 * * \\
(2.51)\end{array}$ & \\
\hline$C O A L I T I O N * N A N G L O$ & & & & $\begin{array}{c}0.485 * * * \\
(3.16)\end{array}$ & \\
\hline COALITION*ASD1 & & & & & $\begin{array}{c}0.114^{* *} \\
(1.98)\end{array}$ \\
\hline COALITION*ASD2 & & & & & $\begin{array}{c}0.448 * * * \\
\quad(3.06)\end{array}$ \\
\hline$D E B T$ & $\begin{array}{c}-0.272 * * * \\
(-2.84)\end{array}$ & $\begin{array}{c}-0.289 * * * \\
(-3.04)\end{array}$ & $\begin{array}{c}-0.289 * * * \\
(-3.04)\end{array}$ & $\begin{array}{c}-0.205 * * \\
(-2.17)\end{array}$ & $\begin{array}{c}-0.255 * * * \\
(-2.66)\end{array}$ \\
\hline SIZE & $\begin{array}{c}-0.063 * * * \\
(-3.76)\end{array}$ & $\begin{array}{c}-0.065^{* * * *} \\
(-3.42)\end{array}$ & $\begin{array}{c}-0.065^{* * *} \\
(-3.42)\end{array}$ & $\begin{array}{c}-0.102 * * * \\
(-4.69)\end{array}$ & $\begin{array}{c}-0.095 * * * \\
(-4.32)\end{array}$ \\
\hline INTANG & $\begin{array}{c}0.335^{* * *} \\
(2.68)\end{array}$ & $\begin{array}{c}0.348^{* * *} \\
(2.89)\end{array}$ & $\begin{array}{c}0.348^{* * * *} \\
(2.89)\end{array}$ & $\begin{array}{c}0.285^{* *} \\
(2.19)\end{array}$ & $\begin{array}{c}0.273 * * \\
(2.16)\end{array}$ \\
\hline$R O A$ & $\begin{array}{c}0.459 * * * \\
(4.40)\end{array}$ & $\begin{array}{c}0.455^{* * * *} \\
(3.29)\end{array}$ & $\begin{array}{c}0.455^{* * *} \\
(3.29)\end{array}$ & $\begin{array}{c}0.387 * * * \\
(3.65)\end{array}$ & $\begin{array}{c}0.352 * * * \\
(3.36)\end{array}$ \\
\hline GROWTH & $\begin{array}{c}0.032 * * * \\
(2.68)\end{array}$ & $\begin{array}{c}0.031^{* *} \\
(2.49)\end{array}$ & $\begin{array}{c}0.031^{* *} \\
(2.49)\end{array}$ & $\begin{array}{c}0.021^{* * *} \\
(3.34)\end{array}$ & $\begin{array}{l}0.015^{*} \\
(1.74)\end{array}$ \\
\hline$L N A G E$ & $\begin{array}{c}-0.128 * * * \\
(-3.76)\end{array}$ & $\begin{array}{c}-0.119 * * * \\
(-3.38)\end{array}$ & $\begin{array}{c}-0.119 * * * \\
(-3.38)\end{array}$ & $\begin{array}{c}-0.161 * * * \\
(-3.48)\end{array}$ & $\begin{array}{c}-0.093 * * \\
(-2.37)\end{array}$ \\
\hline
\end{tabular}


(End of Table 5)

\begin{tabular}{lccccc}
\hline & $(1)$ & $(2)$ & $(3)$ & $(4)$ & $(5)$ \\
\hline Constant & $\begin{array}{c}1.381^{* * *} \\
(4.84)\end{array}$ & $\begin{array}{c}1.393^{* * *} \\
(4.82)\end{array}$ & $\begin{array}{c}1.393^{* * *} \\
(4.82)\end{array}$ & $\begin{array}{c}1.707^{* * *} \\
(5.16)\end{array}$ & $\begin{array}{c}1.715^{* * *} \\
(5.52)\end{array}$ \\
\hline Number of instruments & 63 & 77 & 60 & 74 & 75 \\
\hline $\begin{array}{l}\text { Wald }\left(\mathrm{H}_{0}-\text { test of }\right. \\
\text { equality of interaction } \\
\text { variables })\end{array}$ & 0.011 & 0.035 & 0.0020 & 0.0485 & 0.0443 \\
\hline \begin{tabular}{l}
$\mathrm{m}_{2}(p$-value $)$ \\
\hline $\begin{array}{l}\text { Hansen J-statistics } \\
(p \text {-value })\end{array}$
\end{tabular} & 0.333 & 0.554 & 0.312 & 0.850 & 0.848 \\
\hline $\begin{array}{l}\text { Diff-in-Hansen test } \\
(p \text {-value })\end{array}$ & 0.421 & 0.407 & 0.514 & 0.412 & 0.574 \\
\hline
\end{tabular}

Notes: Figures in parentheses are t-statistics (t-statistics are based on robust, firm-clustered standard errors) while p-values are in brackets. ${ }^{*}, * *$ and $* * *$ indicate statistical significance at 10,5 , and $1 \%$ levels.

circumstances determine the internalization of the consequences of their behaviors and therefore a greater alignment with the interests of other shareholders and by this means a reduction in the importance of contestability as a mechanism for corporate governance; (ii) the fact that the age of family businesses is, on average, lower than that of the other companies (Table 2) may help to explain this result as the contestability effect is lower among younger firms; (iii) the fact that family firms coalitions on average possess more shareholders (Table 2) and, as we demonstrated, for the same level of contestability, the effect on firm value is an inverse function of the number of elements of the coalition.

In model 2 of Table 5 we test if the identity of the second blockholder moderates the contestability effect in family firms. The equality of all coefficients is rejected $(5 \%$ level) by Wald test. Additionally, we could not reject the null hypothesis of the equality of the interaction coefficients pertaining to family firms (COALITION*FFD and COALITION*FNFD) and consequently we reject $\mathrm{H} 3$. When we tested the equality of any of these two interaction variables with the interaction variable concerning nonfamily firms we rejected these hypotheses at the 5\% level.

Subsequently, we created a dummy variable equal to 1 if the two blockholders have the same identity, and 0 otherwise. As can be seen in Table 5 column 3, the coefficient in the case where the two main shareholders belong to the same group is 0.154 , and 0.309 otherwise. Both coefficients are statistically significant at the $1 \%$ level and their equality is rejected at the $1 \%$ level. Thus, our empirical evidence does not support one of the main conclusions for family companies provided by Maury and Pajuste (2005) or Jara-Bertin et al. (2008).

\subsubsection{Legal system}

We explore the interaction of the variable COALITION and the Anglo variable. As shown in the column 4 of Table 5, the coefficient of the variable COALITION is smaller 
for companies from the UK (0.145) than for the other countries in our sample $(0.485)$. The relationship between the contestability of the first largest shareholder and the company value in continental Europe is positive and more influential than for the UK, contradicting what has been suggested by Pagano and Roell (1998). On the contrary, our results validate H4 and the thesis defended by Bloch and Hege (2001).

This result is consistent with the thesis that company-level governance mechanisms might be substitutes for weak country-level governance (La Porta et al. 2002). The results suggest that under a weak legal system, minority shareholders know that only a more balanced distribution of voting rights between the three principal shareholders allows them to anticipate a real ability of the second and third shareholders to contest the decisions of the largest shareholder, which deviates from the purpose of maximizing the wealth of minority shareholders (Bennedsen, Wolfenzon 2000).

Another competing explanation for the contestability effect being greater in continental Europe is that the more concern the major shareholder has regarding the interests of other blockholders, the more democratic decisions will be made, while this concern will be reinforced where other blockholders are aligned in their interests with the minority shareholders.

To test the consistency of this result we split the sample using an anti-self-dealing index (ASD) (Djankov et al. 2008). When we divided the sample with the variable Anglo it could always be said that the difference could result from other factors, such as concentration of ownership in the hands of the main blockholder $(20.37 \%$ in the UK, $43.38 \%$ in the other countries). In the division now proposed this difference is small (for countries with ASD $>0.38^{1}$ ) as concentration of voting rights in the hands of the main shareholder is $27.24 \%$. This regression (model 5 of Table 5) confirms the results as the impact of the contestability effect on firms' value varies according to different legal framework and institutional environment.

\subsection{Robustness tests}

First, we test the contestability effect in line with Konijn et al. (2011) using the GINI variable and Dispersion ratio and Cash-flow ratio (Laeven, Levine 2008) and Contest (Jara-Bertin et al. 2008). The coefficients are in line with those obtained for the variable COALITION. Thus, the contestability effect is robust regardless of the proxy used.

Second, despite using a cut-off point of $10 \%$ of voting rights for identifying a blockholder we decided to test, in line with Laeven and Levine (2008), whether the adoption of a $20 \%$ cut-off level would be relevant (COALITION20 was constructed algebraically with the same formula of COALITION). The results suggest that the choice between $10 \%$ and $20 \%$ did not seem to be relevant.

\footnotetext{
${ }^{1}$ This cutoff, compared to specific values of the sample, allows a closer approximation to our objective, which was to divide the sample into two groups with the same dimension. It has no other significance.
} 
Third, we decided to test the model 3 of Table 4 for the same cut-off but change to considering the sum of voting rights of the three main shareholders. The results are very much in line with that obtained before.

Finally, we decided to test our main results employing a sample that excludes the UK (756 firms and 3035 observations). All results are consistent with the empirical evidence obtained for the full sample (938 firms). As expected, all values of the variable COALITION are greater than those obtained in the full sample. This result is in line with Bennedsen and Wolfenzon (2000), Bloch and Hege (2001).

\section{Conclusions}

First, we document an inverse relationship between the voting rights of the second and third most significant shareholders and agency costs, providing support for the view that minority expropriation will be lower in companies where control is more contestable. Regarding the number of elements of the coalitions, our research suggests that for the same level of contestability the effect on the value of firms is smaller in coalitions with three blockholders when compared to just two blockholders. Taken together, the results suggest a complementarity between "exit" and "voice" governance mechanisms and also the existence of an optimal number of blockholders.

Contrary to Jara-Bertin et al. (2008), we suggest that the contestability effect is stronger when the main blockholder owns less than $50 \%$ of control rights. In line with this result, the contestability effect is equally strong when coalitions do not have a dominant position.

We document that contestability has a weaker positive effect on the company value for family firms when compared to firms with other types of dominant shareholder. This result, which does not confirm previous evidence (Maury, Pajuste 2005; Jara-Bertin et al. 2008), re-launches the question of what mechanisms support the publicized superiority of family firms. Our research also concludes that the coalitions constituted of members that belong to the same group of investors have a substantially reduced effect on the firm's value. However when we analyze the particular case of family firms we do not find evidence that suggests that the identity of who challenges the main blockholder is important.

Finally, our results indicate that, ceteris paribus, contestability in countries with good protection of minority shareholders has a smaller effect on the value of firms when compared to countries with poor legal protection of investors. Thus, although our evidence is contrary to the results of Konijn et al. (2011) for the US it provides support for the idea that the institutional context moderates the contestability effect.

Despite efforts to make sure our analyses are as rigorous as possible, our study is subject to several limitations, which should be addressed in future research. First, we did not have access to information about the difference between control and cash flow rights; second, it might be argued that the number of years for the panel may be short.

The study analyses the effect of complex structures on firm value of large publicly held company in Western Europe. It would be interesting to analyze how our findings for large publicly held companies might change if smaller and private firms were to be examined. 


\section{References}

Aggarwal, R.; Erel, I.; Ferreira, M.; Matos, P. 2011. Does governance travel around the world? Evidence from institutional investors, Journal of Financial Economics 100(1): 154-181. http://dx.doi.org/10.1016/j.jfineco.2010.10.018

Anderson, R. C.; Mansi, S.; Reeb, D. M. 2003. Founding family ownership and the agency cost of debt, Journal of Financial Economics 68(2): 263-285.

http://dx.doi.org/10.1016/S0304-405X(03)00067-9

Arellano, M.; Bond, S. 1991. Some tests of specification for panel data: Monte Carlo evidence and an application of employment equations, Review of Economic Studies 58(2): 277-297. http://dx.doi.org/10.2307/2297968

Arellano, M.; Bover, O. 1995. Another look at the instrumental variable estimation of error component models, Journal of Econometrics 68(1): 29-52.

http://dx.doi.org/10.1016/0304-4076(94)01642-D

Attig, N.; El Ghoul, S.; Guedhami, O. 2009. Do multiple large shareholders play a corporate governance role? Evidence from East Asia, Journal of Financial Research 32(4): 395-422. http://dx.doi.org/10.1111/j.1475-6803.2009.01255.x

Attig, N.; El Ghoul, S.; Guedhami, O.; Rizeanu, S. 2011. The governance role of multiple large shareholders: evidence from the valuation of cash holdings, Journal of Management and Governance http://dx.doi.org/10.1007/s10997-011-9184-3

Barontini, R.; Caprio, L. 2006. The effect of family control on firm value and performance: evidence from continental Europe, European Financial Management 12(5): 689-723.

http://dx.doi.org/10.1111/j.1468-036X.2006.00273.x

Bennedsen, M.; Wolfenzon, D. 2000. The balance of power in closely held corporations, Journal of Financial Economics 58(1-2): 113-139. http://dx.doi.org/10.1016/S0304-405X(00)00068-4

Bloch, F.; Hege, U. 2001. Multiple shareholders and control contests, Working Paper. Aix-Marseille University.

Blundell, R.; Bond, S. 1998. Initial conditions and coment restrictions in dynamic panel data models, Journal of Econometrics 87(1): 115-143. http://dx.doi.org/10.1016/S0304-4076(98)00009-8

Dhillon, A.; Rossetto, S. 2009. Corporate control and multiple large shareholders, Working Paper. University of Warwick.

Djankov, S.; La Porta, R.; Lopez-de-Silanes, F.; Shleifer, A. 2008. The law and economics of self-dealing, Journal of Financial Economics 88(3): 430-465.

http://dx.doi.org/10.1016/j.jfineco.2007.02.007

Edmans, A.; Manso, G. 2011. Governance through trading and intervention: a theory of multiple blockholders, Review of Financial Studies 24(7): 2395-2428.

http://dx.doi.org/10.1093/rfs/hhq145

Fama, E.; Jensen, M. 1983. Separation of ownership and control, Journal of Law and Economics 26(2): 301-325. http://dx.doi.org/10.2139/ssrn.94034

Gomes, A.; Novaes, W. 2006. Sharing of control versus monitoring as corporate governance mechanisms. Mimeo: University of Pennsylvania. http://dx.doi.org/10.2139/ssrn.277111

Jara-Bertin, M.; López-Iturriaga, F. J.; López-de-Foronda, Ó. 2008. The contest to the control in European family companys: how other shareholders affect company value, Corporate Governance: an International Review 16(3): 146-159.

http://dx.doi.org/10.1111/j.1467-8683.2008.00677.x

Jensen, M. C. 1986. Agency costs of free cash flow, corporate finance and takeovers, American Economic Review 76(2): 323-329. http://dx.doi.org/10.2139/ssrn.99580

Konijn, S.; Kräussl, R.; Lucas, A. 2011. Blockholder dispersion and firm value, Journal of Corporate Finance 17(5): 1330-1339. doi:10.1016/j.jcorpfin.2011.06.005 
La Porta, R.; Lopez-de-Silanes, F.; Shleifer, A.; Vishny, R. 2002. Investor protection and corporate valuation, Journal of Finance 58(3): 1147-1170.

http://dx.doi.org/10.1111/1540-6261.00457

Laeven, L.; Levine, R. 2008. Complex ownership structures and corporate valuations, Review of Financial Studies 21(2): 579-604. http://dx.doi.org/10.1093/rfs/hhm068

Lehman, E.; Weigand, J. 2000. Does the governed corporation perform better? Governance structures and corporate performance in Germany, European Finance Review 4(2): 157-195.

http://dx.doi.org/10.2139/ssrn.275834

Maury, B.; Pajuste, A. 2005. Multiple large shareholders and firm value, Journal of Banking \& Finance 29(7): 1813-1834. http://dx.doi.org/10.1016/j.jbankfin.2004.07.002

Pagano, M.; Roell, A. 1998. The choice of stock ownership structure: agency costs, monitoring, and the decision to go public, Quarterly Journal of Economics 113(1): 187-225.

http://dx.doi.org/10.1162/003355398555568

Roodman, D. 2009. A note on the theme of too many instruments, Oxford Bulletin of Economics and Statistics 71(1): 135-158. http://dx.doi.org/10.1111/j.1468-0084.2008.00542.x

Shleifer, A.; Vishny, R. 1997. A survey of corporate governance, Journal of Finance 52(3): 737-783. http://dx.doi.org/10.1111/j.1540-6261.1997.tb04820.x

Villalonga, B.; Amit, R. 2006. How do family ownership, control and management affect firm value?, Journal of Financial Economics 80(2): 385-417.

http://dx.doi.org/10.1016/j.jfineco.2004.12.005

Volpin, P. 2002. Governance with poor investor protection: evidence from top executive turnover in Italy, Journal of Financial Economics 64(1): 61-90.

http://dx.doi.org/10.1016/S0304-405X(02)00071-5

Windmeijer, F. 2005. A finite sample correction for the variance of linear efficient two-step GMM estimators, Journal of Econometrics 126(1): 25-51.

http://dx.doi.org/10.1016/j.jeconom.2004.02.005

Wintoki, M. B.; Linck, J. S.; Netter, J. M. 2012. Endogeneity and dynamics of corporate governance, Journal of Financial Economics 105(3): 581-606.

http://dx.doi.org/10.1016/j.jfineco.2012.03.005

Winton, A. 1993. Limitation of liability and the ownership structure of the company, Journal of Finance 48(2): 487-512. http://dx.doi.org/10.1111/j.1540-6261.1993.tb04724.x

Zwiebel, J. 1995. Block investment and partial benefits of corporate control, Review of Economic Studies 62(2): 161-185. http://dx.doi.org/10.2307/2297801

Mário S. SANTOS received his Master in Management from the ISCTE-Business School. He holds a $\mathrm{PhD}$ in Management from University of Aveiro, Portugal. He is Adjunct Professor at Instituto Politécnico of Coimbra, ISCAC, Portugal. His research interests are mainly in corporate governance, capital structure and behavioral corporate finance.

António C. MOREIRA obtained a Bachelor's degree in Electrical Engineering and a Master's degree in Management, both from the University of Porto, Portugal. He received his PhD in Management from UMIST-University of Manchester Institute of Science and Technology, England. He is Assistant Professor at the Department of Economics Management and Industrial Engineering, University of Aveiro, Portugal, where he headed the Bachelor's and Master's Degrees in Management for five years. His research interests are mainly in strategic management.

Elisabete S. VIEIRA received her Master in Management from the University of Minho. She holds a $\mathrm{PhD}$ in Finance from ISCTE, Portugal. She is Coordinator Professor at the University of Aveiro. Her research interests are mainly in corporate finance, capital structure, dividend policy and behavioral corporate finance. 